\title{
Ruminal environment and forage ruminal digestion in milking cows under grazing and zero-grazing
}

\author{
ML Locatelli 1, DH Rearte 2 \\ 'Cat Nutrición Animal, Dpto Zootecnia, Fac Agr, UBA, Av San Martin 4453, Cap Fed (1425); \\ 2INTA, Dpto Prod Animal, Balcarce, CC 276 (7620), Argentina
}

Cows grazing high quality temperate pasture had a rumen environment characterized by low $\mathrm{pH}$, high $\mathrm{NH}_{3}$ concentration and a low $\mathrm{C}_{2}: \mathrm{C}_{3}$ ratio. A trial was run to study the effect of zero grazing on rumen environment and protein and fiber digestion.

Six Holstein dairy cows with rumen cannula were used under grazing or zero-grazing of a mixed pasture of ryegrass, cocksfoot, phalaris, red clover and white clover during spring time. Pasture offered had $13 \%$ crude protein (CP), $55 \%$ neutral detergent fiber (NDF) and $65 \%$ in-vitro digestibility. Treatments were: T0, strip-grazing (estimated forage utilization 30$50 \%$ ) and $\mathrm{T} 1$, fresh chopped herbage supplied twice a day (estimated forage utilization $80 \%$ ). A cross over design with two treatments and two ten-day periods was used.

Rumen fluid was sampled every 3 hours during $24 \mathrm{~h}$ for each period. Ruminal parameters analyzed were $\mathrm{pH}, \mathrm{NH}_{3}$ concentration (autoanalyzer Technicon) and volatile fatty acids (VFA) concentration (Erwin et al, 1961, J Dairy Sci, 44, 1768). Kinetic forage digestion in the rumen was studied in situ using the nylon bag technique and the model of Ørskov and Mc Donald (1979, J Agric Sci, 90, 463) and Mertens and Loften (1980, J Dairy Sci, 63, 1437) for CP and NDF respectively.

Rumen $\mathrm{pH}$ and VFA concentration were not affected by zero grazing but $\mathrm{NH}_{3}$ concentration was lower and $\mathrm{C}_{2}: \mathrm{C}_{3}$ ratio higher in that treatment. Even when parameters "a" (soluble fraction) and "b" (degradable fraction) of the $\varnothing$ rskov and Mc Donald model for protein kinetic were different, the effective protein degradability adjusted for turnover rate was not affected by zero grazing. For NDF kinetic digestion, only the lag time showed treatment effect being lower in T1.

In conclusion, in the present trial condition, rumen environment of cows on zero grazing were not affected enough to alter kinetic of forage digestion.

\begin{tabular}{|c|c|c|c|}
\hline & TO & $\mathrm{T} 1$ & SEM \\
\hline $\mathrm{pH}$ & 6.5 & 6.5 & 0.04 \\
\hline$\left[\mathrm{NH}_{3}\right](\mathrm{mg} / \mathrm{dl})$ & 10.1 & 5.8 & 2.02 \\
\hline [VFA] $(\mathrm{mmol} / \mathrm{l})$ & 79.3 & 76.8 & 1.57 \\
\hline $\mathrm{C}_{2}: \mathrm{C}_{3}$ ratio & 3.0 & 3.4 & 0.06 \\
\hline CP soluble fraction (\%) & 48.7 & 66.2 & 8.1 \\
\hline CP degradable fraction(\%) & 47.5 & 28.2 & 7.3 \\
\hline $\mathrm{CP}$ degradation rate $(\% / \mathrm{h})$ & 8.4 & 5.5 & 2.1 \\
\hline CP effective degradation (\%) & 82.5 & 82.3 & 2.2 \\
\hline $\operatorname{NDFPDF}^{1}(\%)$ & 76.9 & 71.9 & 5.9 \\
\hline $\mathrm{Kd}^{2}(\% / \mathrm{h})$ & 5.9 & 5.6 & 0.8 \\
\hline Lag time $(h)$ & 3.5 & 0.0 & 0.3 \\
\hline NDF effective degradation (\%) & 43.5 & 45.6 & 5.2 \\
\hline
\end{tabular}

1 NDF potentially digestible fraction

2 rumen turnover rate 